\title{
PENGGUNAAN TEKNOLOGI INFORMASI UNTUK MEMPEROLEH INFORMASI YANG RELIABEL SEBERAPA BESAR EFEK ALIENASI INDIVIDU DALAM MASYARAKAT
}

\author{
Fadhilah Mathar \\ Dosen Fakultas Sains dan Teknologi, Universitas Islam Negeri Syarif Hidayatullah \\ Jalan Ir. H. Juanda No. 95, Jakarta 15412 \\ Telepon +6221-7401925, +62811857551 \\ Email:f.mathar@yahoo.com
}

\begin{abstract}
Alienasi telah menjadi suatu sindrom yang menggejala seiring dengan perubahan pola kehidupan masyarakat, dari pola masyarakat tradisional ke masyarakat modern. Jenis teknologi dan cara menggunakan teknologi dalam kehidupan sehari-hari menentukan seberapa besar efek alienasi yang mungkin menimpa seseorang. Tujuan penelitian ini adalah untuk memperoleh infomasi yang reliabel menyangkut hakikat dan kekuatan hubungan; 1) antara modernitas individu dengan alienasi; 2) antaran tingkat pendidikan dengan alienasi; dan 3) apakah alienasi dapat diprediksi melalui modemitas individu dan tingkat pendidikan secara bersama-sama. Penelitian ini dibatasi pada kajian tentang hubungan antara modernitas individu dan tingkat pendidikan dengan alienasi. Penelitian dilakukan dengan menggunakan metode survei melalui pengembangan berbagai macam kuesioner untuk menghimpun informasi yang berkaitan dengan alienasi individu dalam masyarakat. Hasil penelitian ini menunjukan bahwa terdapat hubungan antara modernitas individu dengan alienasi dan tingkat pendidikan dengan alienasi. Alienasi dapat diprediksi secara bersamaan oleh modernitas individu dan tingkat pendidikan. Kesimpulan ini memperkaya hasil-hasil penelitian lain di berbagai wilayah yang berkaitan dengan tema diatas.

Penelitian lain yang perlu di kembangkan adalah dengan memperbanyak variabel lain yang berkaitan secara kontekstual dengan alienasi seperti jenis kelamin, usia, tingkat pendapatan, kelas sosial, keputusan kerja, dan keterpaan informasi. Suatu penelitian longitudinal barang kali dalah suatu penelitian yang tepat untuk du selenggarakan di masa depan. Penelitian semacam ini diharapakan akan menggali dan mendalami bagaimana proses alienasi melanda individu dan komunitasnya di masyarakat modern.
\end{abstract}

Keywords: teknologi, alienasi, modernitas, pendidikan

\section{PENDAHULUAN}

Perubahan-perubahan sosial yang monumental semakin menggejala di dunia. Perubahan-perubahan tersebut membawa dampak beragam bagi perkembangan lingkungan sosial dan budaya manusia serta turut mempengaruhi internal dan psikologi seseorang. Perubahan-perubahan tersebut mengarahkan transformasi pada sikap manusia. Alienasi merupakan salah satu sikap yang dijelmakan individu dalam merespon perubahan-perubahan sosial itu. Alienasi atau rasa keterasingan dapat di sejajarkan dalam arti sempit dengan keadaan misanthropist yang dialami seseorang. Kondisi tersebut melanda seseorang saat ia mengalami ketersebutaan dari hakikat kemanusiaannya.

Jenis teknologi dan cara menggunakan teknologi dalam kehidupan sehari-hari menentukan seberapa besar efek alienasi yang mungkin menimpa seseorang. Demikian berperannya industrialisasi, perubahan teknologi, dan pembagian lingkup kerja yang sangat detail, menjadikan beberapa jenis pekerjaan terasa sangat membosankan dan tidak membutuhkan keterampilan serta kreativitas yang tinggi. Di

samping itu, intensitas interaksi sosial dalam pekerjaan merupakan faktor yang cukup menentukan apakah pekerjaan tersebut mendatangkan rasa kepuasan tersendiri atau tidak. Dokter, perawat, atau pekerja sosial sering merasa puas dengan kinerjanya karena mereka memiliki tanggung jawab dan komitmen untuk menyembuhkan dan menyelamatkan seseorang dalam tugas kemanusiaan. Hal ini di tegaskan pula oleh Michel Henry yang menginterpretasikan pemikiran Marx bahwa makna kemanusiaan saat ini bukan merupakan 
abstaksi, melainkan makna yang realisasinya muncul dalam masyarakat.

Konsep tentang alienasi pada dasarnya merupakan payung dari konsep-konsep mengenai ketidakberdayaan, ketidakbermaknaan, keterasingan individu dalam masyarakatnya, keterasingan kultural, dan keterasingan pribadi. ${ }^{1}$ Paralelisme dalam keseluruhan subordinasi konsep alienasi diatas adalah adanya suatu manifestasi keterasingan dalam diri manusia dari aspek-aspek penting yang melingkupinya.

Selanjutnya Marx mebedah konsep konsep alienasi dari perspektif sosio-ekonomi. Perkembangan kekinian konsep alienasi menyentuh lingkup ilmu psikologi. Sebagai sebuah ilmu terapan, psikologi merekatkan alienasi beserta dampaknya sebagi perasaan mental yang mebuat seseorang menjadi tidak bertanggung jawab. ${ }^{2}$ Hal tersebut dimungkinkan oleh hilangnya rasa keterikatan antara individu dan aspek aspek sosialnya.

Konsep tentang alienasi menyebar dan mendapat penguatan ketika Karl Marx membahas tuntas ide tersebut dalam bukunya le capital yang diterbitkan pada tahun 1869 .

"L'alieanation de Fouvrier signifie non seulement quw son travai devient un obhet, une existence exteriure, mais que son travail existe en dehors de lui. Independemment de lui, etranger a lui et devient une puissance autonome vis-a-vis de lui, que la vie qui'il apretee a son objet s'oppose a alui ,hostile et eranger."

(Alienasi yang terjadi pada pekerja tidak sekedar menggambarkan kondisi kerja dimana seseorang, merasa pekerjaannya menjadi suatu objek, suatu eksisterior, tetapi juga menggambarkan betapa pekerjaannya telah menjadi sesuatu yang berada di luar dirinya, dan asing baginya bahkan menjadi suatu kekuatan otonom versus dirinya. Ia pun merasa bahwa hidup yang ia jalani terasa antargonis ( kejam), dan beroposisi pada dirinya sendir; terj.,pen.).

Pemikiran Marx;

"S'aliener dans l'economie veut donc dire d'abord pour la vie, d'une manieve encore indeteminee, devenir autre, reventir une nature d'emprurt, etrangere asa nature originelle, laquelle se trouve ainsi falsifiee et perdue. Par une telle alienation les determinations, les lois, les relavation de la vie,enterdons des individus

\footnotetext{
${ }^{1}$ Felix Geyer, Alienation, Society, and Individual: Continuity and Change in Theory and Research,

p.1(http://www.unizar.es/alienationfindice.html).

${ }^{2}$ Igor S. Kon, The Concept of Alienation in Modern Society, pp. $7-10$

(http://www.khasmirforum.com/articles/hariomarticle.html).
}

vivants, deviennent des determinations, des lois, des relations economique."

(Teralienasi dalam ekonomi terutama untuk kehidupan, dapat berarti suatu cara yang menjadikan individu seseorang yang lain, seseorang yang menutup-nutupi hakikatnya, dan merasa asing pada hakikatnya, dan merasa asing bahkan sudah hilang, alienasi semacam itu menjadikan determinasi, hokum, dan hubungan berlandaskan (kepentingan) ekonomi ; terj.,pen).

Marx menyayangkan hilangnya hubungan antar personal yang tergantikan oleh hubungan ekonomi, suatu hubungan yang dianalogikan Marx seperti transaksi antara penjual dan pembeli. Marx menggambarkan alur terciptanya perasaan teralienasi sebagai berikut; mula-mula produksi yang dihasilkan oleh pekerja akan di rebut dari merekan yang menybabkan pekerja merasa dieksploitasi, pekerja tidak lagi bekerja untuk kepentingan diri sendiri tetapi bekerja sekedar untuk mempertahankan hidup, akibatnya, mereka berpikir bahwa apa yang mereka kerjakan hanya diperuntukan bagi musuh mereka (alienasi pada tingkat ekstrim), akhirnya keakuan akan hilang dan digantikan oleh perasaan dehumanisasi.

Jelas tergambar bahwa telaah Marx mengenai alienasi dimulai dari sisi ekonomi. Hal tersebut dapat di pahami karena Karl Mark adalah seorang analist yang bertitik tolak dari pandangan strukturalisme klasik. Ia menganggap bahwa kemiskinan pekerja adalah dampak dari industrialisasi yang erat kaitannya dengan perbaikan sektor ekonomi. Bahkan Marx berpendapat bahwa dalam era industrialisasi, pekerja itu sendiri diperlakukan sebagai komoditas yang dapat diperjual belikan. Kesimpulan demikian diambil oleh Marx setelah ia merujuk perkembangan masyarakat pada masa pra-industrialisasi adalah pekerja menjadi sangat miskin dari masa-masa sebelumnya. Semakin intensif mereka bekerja, maka semakin sedikit produksi yang dapat mereka miliki. Dalam konfigurasi kerja semacam ini, tentu ada pihak yang selalu mengambil keuntungan dan pada titik ini Marx menunjuk pada kaum kapitalis. Namun, Marx menyimpulkan bahwa persamaan dan peningkatan gaji pekerja bukan merupakan jalan keluar dari rasa keterasingan pekerja karena persoalan utama masalah ini bukan di poin itu.

Problema utama dalam sistem kerja kapitalis yang memunculkan rasa keterasingan pekerjanya adalah ketiadaan rasa kepemilikan antara pekerja 
dan hasil yang ia kerjakan. Orang lain yang menguasi produknya. Akhirnya ia merasa tertekan dan teralienasi, bahkan yang lebih buruk, semakin ia giat bekerja, maka kaum kapitalis semakin berkuasa. Akhirnya Marx tiba pada kesimpulan bahwa kepemilikan pribadi tidak akan tercipta tanpa adanya pekerja yang terasing (alienated abour) atau dengan kata lain kapitalisme memunculkan alianted labour. ${ }^{3}$

Paparan di atas tidak dapat lepas dari proposal Marx mengenai sistem masyarakat yang ideal yakni komunis di mana tidak ada lagi kelas sosial dan kepemilikan harta tunggal pada seseorang atau kaum tertentu, melainkan di bagi rata pada setiap individu dalam masyarakat (komunal). Meskipun studi Marx diletakan di atas perspektif ekonomi, setidaknya ada bebrapa komponen yang menyentuhkan konsep alienasi dengan faktor psikologi manusia. Menurut Marx alienasi ditandai oleh beberapa symptom psikoligis seperti hilangnya keakuan individu, munculnya perasaan tidak bahagia, pekerjaan dianggap suatu bentuk ketidakpaksaan, yang akhirnya menurunkan kualitas mental dan pikiran.

Marx membagi alienasi pada masyarakat kapitalistik ke dalam empat bentuk yaitu:

"Fist ; Alienation of human beings from the products of their work. The products of the workers' labor are not their own. They belong to another (who owns the material and means of production and who gets the profil). The more workers put of themselves into product, the less are themselves, second; alienation of human beings from the act og producing (labor). Workers do not produce willingly, but their labor is coerced. They are "not themselves" when they are working. Their existence as "labor" is an object alienated from their own lives. They can only :be" themselves after work. They wuld not work if they did not haveto in order to maintain their life outside of the factory is reduced to the animal functionof eating, sleeping, and reproduction, third alienation of human beings from their own sosial ( species or universal) nature. Human beings, unlike animal do not create and personal needs; fourth, alienation of human beings from non-human physical nature (objects of nature). Human workers use objects of nature(material) which they do not own to

${ }^{3}$ Ibid, p. 9 make object of production (products) which they also do not own ."

(Pertama; alienasi manusia dari hasil produksi mereka sendiri. Produk yang di hasilkan pekerja bukan milik mereka pribadi, melainkan milik orang lain (yang memegang kuasa penuh pada sarana dan prasana produksi serta keuntungan yang diperoleh). Semakin banyak pekerja yang mebenamkan diri pada proses produksi, semakin sedikit mereka memperoleh keuntungan. Kedua; alienasi manusia dari kegiatan memproduksi. Karyamwan tidak bekerja secara suka rela, tetapi pelerjaan memaksa demikian. Mereka bukan lagi diri mereka saat bekerja. Eksistensi mereka sebagai pekerja adalah objek yang ideal untuk mengasingkan mereka dari kehidupan mereka sesungguhnya. Mereka dapat menjadi diri sendiri hanya setelah selesai bekerja. Mereka bekerja karena mereka harus mempertahankan kesehatan fisik mereka. Mereka merasa seperti hewan di dalam pabrik dan kehidupan mereka diluar pabrik tereduksi menjadi sekedar makan, tidur, dan melakukan reproduksi sebagaimana layaknya siklus hidup hewan. Ketiga; alienasi manusia dari hakikat kehidupan sosial mereka sendiri. Tidak seperti hewan, manusia menciptakan sesuatu bukan sekedar untuk memberi suatu kontribusi bagi spesies (manusia) lain dalam rangka membentuk kebudayaan manusia ingin menciptakan teknologi atau pengetahuan atau produk untuk kepentingan seluruh ras manusia. Kebutuhan universal ini telah dirusak oleh produksi industrial dan mereduksi karya manusia menjadi sekedar sarana pemuasan kebutuhan pribadi untuk waktu yang singkat. Keempat; alienasi manusia dari aspek non manusia (alam). Manusia bekerja dengan mengguanakan hasil alam (material) yang bukan milik mereka. ; ter.,pen.)

Dari paparan di atas ditemukan bahwa setidaknya terdapat bentuk alienasi manusia yaitu alienasi manusia dari hasil produksi mereka, proses produksi, dunia sosial atau manusia lain, dan dari alam.

Simultan dengan Marx, teori lain menunjukkan bahwa kapitalisme sebagai suatu sistem ekonomi berkaitan dengan sistem politik yang berlaku dimana keterkaitan itu menimbulkan alienasi pada individu. Kesenjangan ekonomi adalah suatu hal yang dialami dalam masyarakat yang memonopoli kekayaan atau modal dan ada kelas yang dilingkupi oleh kemiskinan. Kemiskinan 
bertautan dengan alienasi dengan penjelasan sebagai berikut; pada awal erakapitalisme, hubungan sosial ditandai oleh munculnya rasa keterasingan pada kelas pekerja di pabrik dan akumulasi modal oleh kaum kapitalis. Seiring dengan meningkatnya produksi massal di pabrikpabrik, identitas pekerja berkembang dari pengelola mesin menjadi mirip dengan mesin itu sendiri (terjadi eksploitasi), dan akhirnyapada tingkatan tertentu seluruh aktivitas pekerja tersebut dapat di fungsikan secara mandiri oleh mesin. Peran manusia telah tergantikan oleh mesin. Mekanisasi menjadikan manusia mengalami alienasi.

Ekonomi perdagangan terbentuk oleh pertukaran hasil produksi manusia. Dalam proses tersebut, manusia menjadi komoditi di mana uang memainkan peranan signifikan. Hakikat manusia telah tereduksi. Secara tegas, Marx menggaris bawahi bahwa ketika sirkulasi uang terus berjalan, akan muncul suatu pola hubungan yang baru yaitu peran penjual-pembeli akan menjelma kreditur debitur. Pada fase ini, individualitas telah dinegasikan oleh ekonomi.

Marx membangun teorinya pada konteks ekonomi. Disisi lain, konteks tersebut dapat disempitkan pada hubungan personal di dunia kerja, sehingga alienasi dapat didefinisikan sebagai: the condition where workers have no job satisfaction or fulfillment from their work. Work becomesmeaningless and workers have an aexrinsic or instrumental attitude to their job (alienasi adalah suatu kandisi di mana pekerja/karyawan tidak memperoleh kepuasan atau kegembiraan lagi dari pekerja mereka.; terj., pen.). Beberapa pemikiran mensintesakan konsep tentang alienasi, dua di antaranya adalah pemikiran Marxist dan pemikiran Blauner.

Selaras dengan basis teori Marx tentang hubungan ekonomi yang telah dijelaskan di atas, maka Marx berpandang bahwa alienasi terjadi karena pekerja kehilangan kekuatan dan terlampau dieksploitasi di dunia kerja mereka oleh kaum kapitalis;

Karl Marx believed that the cause of alienation is the lack of power of the workers gripped the increasing exploitation of their work. workers and profits fall to the factory-owner of the capitalists. Not infrequently, workers can not even afford what they produce themselves,.)

(Karl Marx meyakini bahwa penyebab alienasi adalah semakin minimnya kekuatan para pekerja dean semakin meningkatnya eksploitasi dalam pekerjaan mereka . pekerja dan keuntungan jatuh ke pemilik pabrik-kaum kapitalis. Tidak jarang, pekerja bahkan tidak mampu membeli apa yang mereka produksi sendiri., terj.,pen.).

Di satu pihak, terlihat bahwa Karl Marx secara implisit menuduh hilangnya posisi tawar menawar pekerja dalam suatu proses produksi sebagai faktor penyebab timbulnya alienasi. Dilain pihak, Marx mengklaim bahwa kaum kapitalis telah melakukan eksploitasi terhadap pekerjanya.

Hampir mirip dengan perspektif Marx, Erich Fromm berpendapat bahwa alienasi merupakan suatu kondisi saat manusia tidak merasa lagi sebagi prilaku aktif bagi setiap tindakannya. Ia merasa semua yang ia hasilkan bukan berasal dari kekuatan dan kekayaannya sendiri, sebaliknya ia merasa dirinya sebagai "benda" lemah yang selalu bergantung kepada kekuatan di luar dirinya. Pada kekuatan itulah ia menambatkan substansi hidupnya.

Fromm menjelaskan kondisi di atas dari perspektif sosial, terutama di masyarakat kapitalis modern. Fromm memaparkan konsep ketidak berdayaan dan keterasingan manusia dengan sangat jelas. Namun konsep ketidak berdayaan versi Fromm memperoleh karakter global. Ia menggabungkan konsekuensi otomatisasi sosial, pembagian kerja, dan ketidakberdayaan manusia dengan hakikat spontan perkembangan masyarakat. Menurutnya alienasi mengimplikasikan adanya reduksi totalitas individu menjadi fungsi-fungsi sosial parsial dan keterasingan individu dari peran sosialnya. Dengan kata lain, alienasi merupakan suatu perwajahan masyarakat modern yang dipenuhi oleh komleksitas masalah. ${ }^{4}$

Untuk memahami konsep alienasi dalam aneka makna, maka jalan terbaik adalah menelusuri kembali sejarah perkembangannya dari berbagi lintasan ilmu. Berikut ringkasan singkat mengenai perkembangan teori alienasi yang menjadi variabel terikat dalam penelitian;

The concept of alienation is an ancient one. Saint Augustine wrote that due to its sinful nature, humanity was alienated from God. He believed that a reconciliation could be achieved through belief in Christ. Karl Marx gave an economic interpretation to alienation. People were alienation from their own labor, their work was appropriated by someone else and the work

\footnotetext{
${ }^{4}$ Herbert Marcuse, Eros and Civilization: A Philosophical Inquiry into Freud (New York, 1962), p. 43.
} 
itself was compulsory, not creative; the cause was capitalism, and the cure was sosialism. To Sigmund Freud, alienation was selfestrangement caused by the split between the conscious and unconscious parts of the mind. Sociology provided another viewpoint: Emile Durkheim's anomie, of rootlessness, stemmed from loss of social and religious tradition. Later sociologists further expanded Durkheim's, theme of alienation. The existentialists Soren Aabye Kiekegaard, Martin Heidegger, and Jean-Paul Sartre saw some measure of self-estrangement and powerlessness over one's destiny as inevitable part of the human condition. ${ }^{5}$

Alienasi menjadi suatu sindrom yang menggejala seiring dengan perubahan pola kehidupan masyarakat dari pola tradisional ke modern atau dari masyarakat feodal ke arah kapitalistik. Perubahan masyarakat itu sendiri adalah fenomena yang patut dicermati. Kesiapan kultur dan mental manusia menghadapi globalisasi dan segala dampaknya merupakan pertanyaan besar yang dikedepankan oleh para sosiologi dalam menelaah alienasi dari konteks modernitas. Artinya, faktor psikologi dan faktor sosiologis adalah dua hal yang perlu mendapat perhatian sebagai kontributor kajian alienasi secara holistis.

Alienasi telah menjadi sindrom pada masyarakat modern yang semakin lama semakin kehilangan rasa kepemilikan atas dirinya sendiri. Pembahasan indutrialisai, perubahan teknologi, dan pembagian lingkup kerja secara langsung mengarahkan telaah penelitian ini pada modernisai sebagai wadah dari indutrialisasi, perubahan teknologi, dan pembagian lingkup kerja tersebut.

Pada tataran tersebut, modernitas individu menjadi salah satu faktor yang perlu dibahas ketika seorang meneliti tentang alienasi. Modernitas, modern, modernisasi adalah tiga kata yang berakar dari kata yang sama tetapi memberi aksentuasi yang berbeda satu sama lain. Menjelaskan faktor modernitas dalam kaitannya dengan alienasi merupakan suatu persoalan tersendiri karena kedua terminologi tersebut, sebagaimana konsep-konsep lain dalam sosiologi, sama-sama memaparkan aneka dimensi yang bila tidak saling mendukung, maka akan saling bertentangan. Ketelitian dan kepatuhan dalam metode ilmiah akan menuntun peneliti menemukan paralelisme dalam setiap persamaan atau perbedaan konsep itu.

Modernisasi merupakan salah satu tema utama yang mendominasi diskursus masyarakat barat sejak 500 tahun yang lau. Wacana tersebut kemudian juga mempengaruhi pemikiran sosiolog-sosiolog dunia Timur. Perspektif tentang pemikiran modern berakar pada perubahan sosial dan intelektual pada abad XII dan XIII yaitu saat terjadi desentralisasi perekonomian dari ekonomi berbasis pertanian menjadi perdagangan dan munculnya masyarakat perkotaan.

Pernjelasan paling sederhana mengenai modernitas selalu merujuk pada waktu yang menetapkan batasan zaman yang berbeda dari masa lampau. Begitu mendengar kata modern, maka masyarakat cenderung mengasosiasikannya dengan suatu rezim baru, suatu percepatan, suatu perpecahan, atau suatu revolusi waktu. Konsep modernitas menyajikan 2 (dua) perwajahan; menang dan kalah serta tradisional dan modern yang berjalan di atas rel waktu yang terputus. Pandangan ini hanya salah satu konsep simplisitas dalam memaknai modernitas individu. Antitesis terhadap ide tersebut lebih tajam dipaparkan dalam Bab II. Disamping itu, simplisitas tersebut mengidikasikan adanya permasalahan dan kesenjangan pada konsep dan fakta tentang modernitas.

Salah satu karakteristik masyarakat modern adalah adanya diferensiasi kerja. Diferensiasi tersebut bertautan langsung dengan beberapa faktor yang mendukung kompetisi seseorang. Kompetisi akan mengarah kepada proses pembentukan occupational prestige seorang dan salah satu faktor yang berkaitan dengan hal tersebut adalah tingkat perndidikan. Adapun pendidikan dalam penelitian ini akan menitik beratkan pada pendidikan formal seseorang.

Pada tahap ini, tingkat pendidikan menjadi satu kajian yang perlu disinergiskan dengan studi pustaka pengenai alienasi dan modernitas individu. Akhirnya, fenomena-fenomena di atas melatarbelakangi peneliti untuk menyelenggarakan penelitian ini.

Permasalahan dalam penelitian ini akan dibatasi pada kajian tentang hubungan antara modernitas individu dan tingkat pendidikan dengan alienasi. Mulai dari penelitian hubungan antara modernitas individu dengan alienasi, hubungan antara tingkat pendidikan dengan alienasi, dan hubungan antara modernitas individu dengan tingkat pendidikan secara bersama sama dengan alienasi. Alienasi dan modernitas individu diteliti berdasarkan dimensidimensi yang nantinya akan diperoleh dari perkembangan kajian teotritis dan kerangka bepikir. Sedangkan analisa seseorang mengenyam pendidikan formal.

Sejalan dengan permasalahan yang akan di bahas, penelitian ini meiliki keguanaan: 1) untuk mengetahui terminologi alienasi, modernitas individu, dan tingkat pendidikan secara konseptual: 2) untuk memperoleh informasi 
mengenai besarnya pengaruh tingkat pendidikan dengan alienasi: 3) untuk memperoleh informasi mengenai besarnya pengaruh modernitas individu dengan alienasi: 4) untuk mengetahui besarnya pengaruh antara tingkat pendidikan, modernitas individu dengan alienasi: 5) diharapkan kajian ini juiga berguna sebagai masukan dan awal bagi penelitian serta kegiatan kegiatan akademis lain.

\section{BAHAN DAN METODOLOGI PENELITIAN}

Tujuan penelitian ini adalah untuk memperoleh infomasi yang reliabel menyangkut hakikat dan kekuatan hubungan; 1) antara modernitas individu dengan alienasi; 2) antaran tingkat pendidikan dengan alienasi; dan 3) apakah alienasi dapat diprediksi melalui modemitas individu dan tingkat pendidikan secara bersama-sama.

Penelitian ini bertujuan menghimpun pula informasi mengenai salah satu dimensi sosiopsikologi dalam masyarakat yang belum banyak terungkap yakni alienasi. Diharapkan melalui konten itu, beberapa program sosial dan kependidikan dapat dikembangkan dengan pemakluman ekstra terhadap kondisi internal tersebut. Dengan demikian, khazanah pendidikan akan dimaknai lagi oleh satu varian, yaitu alienasi.

Penelitian ini mengajukan 3 variabel yang terdiri dari 2 variabel bebas (modernitas individu dan tingkat pendidikan) dan 1 variabel terikat (alienasi). Dari paparan teori, dapat disimpulkan bahwa alienasi adalah suatu kondisi keterasingan yang dialami oleh individu yang ditandai dengan; 1) ketidakberdayaaan (powerlessness) dimana individu tidak memiliki kendali atas keputusan-keputusan yang dibuat dalam pekerjaan atau dengan kata lain individu tidak memiliki kendali atas apa yang ia kerjakan; 2) ketidakbermaknaan (meaninglessness) mana individu terasa tak bermakna. Ia pun merasa jenuh karena dalam tahap akhir keputusan hanya sedikit orang yang berperan. Di samping itu ia merasa eksektasi untuk memenuhi tujuan tertentu melebihi kemampuan yang ia miliki; 3) isolasi sosial (sosial isolation) dimana pekerja diisolasi dari rekan lainnya dan persahabatan sulit dilakukan serta pekerja merasa serpeti satu komponen dalam mesin sehingga menimbukan rasa penolakan bagi dirinya; 4) keterasingan individu (selfestrangement), kondisi di mana pekerja merasa potensinya belum sempurna, artinya tanpa kreativitas personal atau ekspresi diri pun, siapa saja dapat melakukan pekerjaannya; 5) kerterasingan budaya (cultural estrangement) adalah suatu kondisi dimana seseorang merasa bingung akan nilai sosial yang dianut oleh masyarakat dan cenderung, menolak nilai tersebut dan di samping itu ia merasa terserabut dari akar budayanya sendiri.

Tempat penelitian ini adalah di kelurahan Utan Kayu Selatan, Jakarta Timur. Pemilihan kelurahan tersebut didasarkan pada keanekaan dimensional masyarakatnya dan jaraknya yang dekat sehingga menghemat waktu dan biaya penelitian. Jumlah penduduk kelurahan Utan Kayu Selatan adalah 39.014 jiwa dengan luas wilayah 112.22 Ha. Dari total jumlah penduduk tersebut 15.812 orang di antaranya adalah perempuan dan selebihnya adalah laki-laki yakni 23.202 jiwa.

\subsection{Metode Penelitian}

Sesuai dengan tujuan penelitian ini yakni untuk memperoleh informasi yang berkaitan dengan status gejala pada saat penelitian dilaksanakan, maka metode yang digunakan dalam penelitian ini adalah metode survei. Dimensi alienasi individu dalam masyarakat pun dapat diukur melalui metode survei.

Berbagai macam kuesioner telah dikembangkan untuk menghimpun informasi mengenai alienasi melalui metode survei, salah satu kuesioner yang cukup sering digunakan adalah Skala Alienasi Seeman. Meskipun peneliti tidak mengaplikasikan Skala Alienasi Seeman dalam penelitian ini, namun konsep alienasi yang dikembangkannya merupakan landasan utama penyusunan indikator dan dimensi dalam penyusunan instrumen penelitian.

\subsection{Teknik Pengambilan Sampel}

Populasi adalah serangkaian data yang mencirikan gejala-gejala tertentu. Populasi juga bermakna sebagai jumlah keseluruhan dari unit analisis yang ciri-ciri akan diduga dan dapat dbedakan menjadi populasi sasaran (target) dan populasi terjangkau. Populasi sasaran (target) dalam penelitian ini adalah masyarakat di kelurahan Utan Kayu Selatan Jakarta Timur, sedangkan populasi terjangkau adalah kepala keluarga di tingkat Rukun Warga.

Berikut penentuan sampel multisage random sampling yang diterapkan dalam penelitian ini; 1) penelitian menggunakan purposive sampling dalam menentukan wilayah penelitian. Dengan mempertimbangkan faktorefisiensi dan efektivitas, maka dipilihlah kelurahan utan kayu selatan sebagai wilaya penelitian; 2) penentuan rukun warga dilakukan dengan cluter sampling. Dari 14 Rukun Warga di Utan Kayu Selatan, dipilih lima Rukun Warga yakni RW 01, RW 02, RW 13, RW 4, dan RW 03; 3) masih dengan menggunakan cluster sampling, ditentukan masing-masing 2 RT yang merupakan reprsentasi kelima RW di atas. Sehingga total RT adalah 10; 4) Tahan terakhir dari multisage random sampling ini adalah menentukan kepala 
keluarga yang dijadikan subjek penelitian dengan simple random sampling. Dari masing-masing RT yang berjumlah 10, dipilih 10 keluarga secara acak sederhana.

Dengan demikian jumlah keseluruhan kepala yang menjadi sampel adalah 10 orang/RT sama dengan 100 orang. Berdasarkan laporan bulan setember kelurahan utan kayu selatan, terdapat 12.309 kepala keluarga yang tersebar di 173 RT dan 14 RW.

\subsection{Teknik Pengumpulan Data}

Sesuai jumlah variabel, maka terdapat 3 jenis informasi yang akan dikumpulkan dalam penelitian ini. Tiga informasi tersebut mencakup tingkat modemitas individu, tingkat pendidikan, dan tingkat alienasi. Ketiga jenis data yang berbentuk skor tersebut dihimpun dengan menggunakan teknik wawancara dengan menggunakan instrumen berbentuk kuesioner.

Peneliti memilih teknik wawancara karena salah satu variabel dalam penelitian ini adalah tingkat pendididkan, di mana diasumsikan responden-responden tertentu yang berpendidikan rendah akan menemui hambatan besar bila diharuskan mengisi angket karena ketunaaksaraaan mereka. Wawancara pada seluruh responden dilakukan secara mandiri oleh peneliti.

\section{HASIL DAN PEMBAHASAN}

Pada bagian ini, peneliti akan menguraikan 4 komponen utama yakni (1) deskripsi data; (2) pengujian hipotesis; (3) diskusi,dan (4) keterbatasan penelitian. Uraian hasil penelitian ini akan menyajikan deskripsi data yang mencakup ukuran pemusatan (maen, media, modus ) dan ukuran pesebaran (standar deviasi).

\subsection{Deskripsi Data}

Deskripsi data berikut berasal dari data hasil wawancara yang bersandar pada intrumen penelitian yang telah didistribusikan. Skor masing-masing variabel yaitu alienasi modernitas individu, dan tingkat pendidikan akan dipaparkan sebagai berikut:

1. Skor Alienasi

Dari hasil pengolahan data diperoleh deskripsi sebagai berikut; secara teoritik rentangan skor variabel alienasi berkisar antara 41 - 123. Rentang skor untuk variabel alienasi adalah skor tertinggi adalah 107 dan terendah 46 dengan media 70,00, mean 72,86, dan modus 74,00. Adapun standar deviasi untuk variabel ini adalah 14,41.

2. Skor Modernisasi Individu

Dari hasil pengolahan data diperoleh deskripsi sebagai berikut; rentangan skor teoritik variabel untuk modernitas individu adalah 40-120. Adapun rentang skor tertinggi untuk variabel modernitas individu adalah 111 dan terendah 53 median 75,00, mean 75,44 dan modus 83. Sedangkan standar deviasi untuk variabel ini adalah 14,22.

3. Skor Tingkat Pendidikan

Dari hasil pengolahan data tingkat pendidikan diperoleh deskripsi sebagai berikut; rentang skor untuk variabel tingkat pendidikan tertinggi adalah 19 dan terendah 0 dengan median 12,00, mean 10,60 dan modus 17 . Adapun standar deviasi untuk variabel ini adalah 5,64.

\subsection{Persyaratan Analisis}

Persyaratan analisis merupakan suatu tahap yang diperlukan untuk mencermati data tertentu sebelum analisis regresi dilakukan. Persyaratan pertama yakni keabsahan samples telah dipenuhi dengan metode pengambilan sample secara acak dan memenuhi sampel minuman dengan jumlah 100 sampel. Kemudian peneliti melakukan uji normalitas yang berpengaruh terhadap penentuan bentuk pengujian hipotesis selanjutnya. Uji normalitas dimaksud untuk mengkaji apakah respon-respon $\mathrm{Y}$ independen dan berdistribusi normal terhadap setia kelompok harga prediktor $\mathrm{X}$. Tahapan terakhir dalam persyaratan analisis ini adalah menguji setiap kelompok harga $X$, di mana masing-masing variansi OYX homogen. Persyaratan analisis kedua yakni uji normalitas dilakukan dengan menggunakan uji Kolmogorov-Smimov dengan asistensi aplikasi SPSS 10.0 for Windows, dan output pengujian ini adalah sebagai berikut; hasil uji normasi dengan menggunakan Test kolmogorov-Smimov untuk masing-masing variabel penelitioan yakni alienasi (Y,) Modernitas Individu (X1), dan Tingkat Pendidikan (X2).

Populasi untuk variabel alienasi berdistribusi normar karena a-max < D-tabel. Pada baris most extreme tampak bahwa nilai absolut untuk variabel alienasi adalah 0,121 , sedangkan DTabel untuk $\mathrm{n}=100$ (di atas 35) dan probabilitas $=0,05$ adalah 0,188. Kriteria pengujian normalitas ini adalah tolak Ho bila a maksimum > daripada D-Tabel dan terima Ho bila a maksimum D-Tabel. Dari hasil pengujian ini ditemukan a maksimum 0,121 < 0,118 D-Tabel sengga Ho diterima pada $@=0,05$. Hal ini berarti data populasi berdistribusi normal. Di samping a max untuk variabel alienasi, a max untuk variabel modernitas individu dan tingkat pendidikan juga lebih besar daripada D tabel. Dari Tabel diatas tampak bahwa untuk variabel modernitas individu a $\max =0,149, \mathrm{D}$ Tabel $=$ 0,188 .

\section{Hubungan Antara Tingkat Pendidikan dengan Alienasi}


Hipotesis penelitian yang diajukan dalam penelitian ini adalah terdapat hubungan berbanding lurus antara tingkat pendidikan dengan alienasi. Artinya, semakin tinggi tingkat pendidikan seseorang maka makin tinggi pula tingkat alienasinya. Berdasarkan hasil analisis statistik, diperoleh koefisien korelasi sebesar 0,667. Dari koefisien tersebut diperoleh t-hitung $=8,86$ yang lebih besar dari t-tabel $=1,89$ dengan $n=100$. Nilai tersebut mengindikasikan besarnya kekuatan hubungan antaran tingkat pendidikan dengan alienasi. Koefisien korelasi tersebut sangat singnifikan sehingga dapat dinyatakan bahwa hipotesis nol yang berbunyi tidak terdapat hubungan berbandi ng lurus antara tingkat pandidikan dengan alienasi ditolak. Dengan kata lain, semakin tinggi tingkat pendidikan seseorang maka makin tinggi pula tingkat alienasinya.

Analisis yang lebih mendalam menunjukkan bahwa besarnya kontribusi modernitas individu terhadap variasi alienasi adalah $44 \%$. Hubungan antara tingkat pendidikan dengan alienasi dinyatakan melalui persamaan $\mathrm{Y}=54,78+1,17$ $\mathrm{X} 2$ yang sangat signifikan dan memiliki bentuk hubungan linier.

Secara visual, kekuatan hubungan antara tingkat pendidikan (X1) dengan alienasi (Y) untuk sampel petani dengan model (hakikat hubungan $\mathrm{Y}=54,78+1,71 \mathrm{X} 2$ dapat dilihat. Kedua variabel prediktor tersebut (modernitas individu dan Tingkat pendidikan) secara bersama-sama memberikan kontribusi kepada variasi alienasi sebesar 25\%. Model hubungan antara kedua variabel prediktor itu dengan alienasi dinyatakan melalui persamaan $\mathrm{Y}=34,45$ $+0,38 \mathrm{X} 1+0,92 \mathrm{X} 2$ yang ternyata sangat signifikan. Hal ini berarti hipotesis nol yang menyatakan tingkat alienasi tidak dapat diprediksi secara bersama-sama oleh modernitas individu dan tingkat pendidikan ditolak.

\section{Prediksi Terhadap Tingkat Alienasi Secara Bersama-sama}

Dengan Modernitas Individu dan Tingkat Pendidikan dalam penelitian ini diajukan hipotesis penelitian yang menyatakan bahwa tingkat alienasi dapat diprediksi secara bersamasama oleh modernitas individu dan tingkat pendidikan. Pengujian terhadap hipotesis tersebut dilakukan pada sampel kedua variabel prediktor X1 dan X2 yang terbukti memiliki hubungan signifikan dengan variabel $Y$ (alienasi). Berdasarkan hasil analisis, koefisien korelasi jamak yang diperoleh adalah sebesar 0,49 yang ternyata sangat signifikan.

\section{KESIMPULAN}

Merujuk kepada pengujian hipotesis,beriku ini disajikan interpretasi terhadap hasil pengujian tersebut. Telah terhadap interpertasi akan mengarahkan penelitian dan kegiatan akademis lainnya. Pada akhir bab ini akan dipaparkan saran-saran bagi penelitian dan kegiatan akademi lainnya.

Pertama, terdapat hubungan positif antara modernitas individu dengan alienasi. Artinya, makin tinggi tingkat modernitas individu maka makin tingi pula tingkat alienasi individu tersebut. Kekuatan hubungan antara kedud varibel tersebut ditunjukkan dengan koefisien korelasi sebesar 0,009 dengan model regresi linear sederhana $\mathrm{Y}=21,70+0,68 \mathrm{X} 1$. Pengontrolan terhadap varibel tingkat pendidikan menghasilkan koefisien korelasi parsil sebesar 0,29. Kontribusi modernitas individu terhadap alienasi adalah sebesar $45 \%$.

Salah satu karakteristik modernitas individu adalah individu modern bersentuhan erat dengan infomasi (keterpaan informasi ). Unik, dari tinjauan teori alienasi ditemukan bahwa anggota masyarakat modern cenderung lebih memperhatikan infomasi tidak ada relevansinya dengan aktivitas mereka. Kesimpulan ini juga menunjukkan bahwa informasi sudah tidak menjadi kebutuhan utama mereka karena informasi yang ada mereka anggap terlalu jauh dari kenyataan hidup mereka sehari-hari.

Secara implisit, hasil studi itu menunjukan bahwa indikator keterpaaan informasi dalam masyarakat modern juga dapat menjadi indikasi munculkan alienasi individu dalam masyarakat. Hasil penelitian tersebut perlu ditindaklanjuti melalui suatu kajian ulang mengenai keterpaan informasi dalam masyarakat modern secara maknawi.

Merujuk pada kontribusi positif modernisasi, setiap individu modern, terutama pekerja menegah ke atas, memiliki identitas positif dan penghargaan pada diri sendidri. Namun beberapa penelitian menyimpulkan bahwa kondisi tersebut tidak berlaku pada banyak orang. Bahkan pekerjaan menyebabkan seseorang merasa terasing baik dari pekerjaannya, dari orang lain, maupun dari aspek lain hidupnya. Makna dari hasil kajian tersebut adalah bahwa pekerjaan yang dilakukan oleh individu di masa modern berpotensi mengasingkan ia dari hakikatnya, sebagaimana berpotensi pula membawa mereka pada aktualisasi diri yang mendalam.

Salah satu pembeda masyarakat modern adalah minimalisasi penggunaan tenaga manusia dalam segala bidang yang digantikan oleh optimalisasi teknologi. Salah satu hasil dari teknologi adalah telepon genggan (handphone / mobile phone). Di satu sisi modernisasi menimbulkan alienasi, namun disisi lain modernisasi juga telah menciptakan kaidahnya 
sendiri untuk mereduksi alienasi tersebut. Suatu penelitian tentang alienasi menunjukan bahwa bergosip melalui telepoin genggam terbukti menjadi terapi tersendiri bagi masyarakat yang hidup di dunia modern yang teralienasi.

Diasumsikan bahwa Jakarta sebagai kota kosmopolitas, tentu memiliki penduduk yang bersikap dan berperilaku modern secara keseluruhan. Namun, asumsi tersebut tidak selamanya dapat diterima, seperti pada penelitian ini dimana ditemukan bahwa ternyata (secara interpretastif) ditemukan ternyata wilaya geografis bukan merupakan satu-satunya faktor pembentuk modernitas individu. Masyarakat Jakarta, terutama mereka yang pendatang cenderung tetap memegang kukuh budaya dan etos tradisional serta memiliki deviasi-deviasi dari kultur modernitas ala Barat. Perwajahan ambiguini akan menjadi suatu kajian penting lainnya.

Kedua, terdapat hubungan positif antara tingkat pendidikan dengan alienasi. Artinya, makin ttinggi tingkat penididikan maka makin tinggi pula tingkat alienasi orang tersebut. Kekuatan hubungan antaran kedua variabel tersebut ditunjukkan dengan koefisien korelasi sebesar 0,667 dengan modern regresi linear sederhana $\mathrm{Y}=54,78+1,70 \mathrm{X} 2$. Pengontrolan terhadap variabel 0,28. Kontribusi tingkat pendidikan terhadap alienasi adalah sebesar $44 \%$. Beberapa studi empiris menujukkan hubungan antara alienasi dengan tingkat pendidikan dalam berbagai konteks. Kasus yang menarik adalah penjelasan mengenai sindrom alienasi pada orang tua.sinndrom tesebut dinyatakan sebagai bentuk modern dari fobia terhadap sekolah yang menimpa peserta didik.fobia semacam itu seperti juga perceraian, akan menimbulkan perasaan keterasingan pada seseorang.

Suatu studi longitudinal diselenggarakan di pabrik-prabrik di Kazan, Rusia. Studi tersebut hendak mengkaji tingkat alienasi tidak terlalu senjang dibandingkan dengan tingkat pendidkan. Daya jelas tersebut menurun bila salahsatu variabel dikontrol. Alienasi korelasi parsil membukti bahwa telah terjadi penurunan koefisien korelasi baik jika variabel modernitas individu dijelaskan sebagai bentuk keeratan hubungan antara modernitas individu dengan alienasi individu. Beberapa implikasi dapat dikedepankan berrdasarkan kesimpulah diatas.

\section{DAFTAR PUSTAKA}

Abdul Rauf, La Ode. Peranan Elit dalam Proses. Modernisasi, Suatu Studi Kasus di Muna. Jakarta: Balai Pustaka, 1999.
Anonim. Alienation. http://www/search.britannica.com/com/search/re sult/alienation.html.

Anonim. Concept of Justice.

http://www.alien/american.edu/dgolash/3earlyma rx01.html.

Beacher, Peter. New Apporoachesin the Danish Education System: The Learning Society.Ed. Elisabeth Dunne: Kogam Page, 1999.

Banai, Moshe and Jacob Weisbeng. Alienation in the Private and the Public Sectors in Russia.http//:www.sbaer.uca.edu_Reseacrh/1999 /SRIBR/99sri065.htm.

Bardo, John W., Hartman John J. Urban Sociology: A Systematic Intoduction. New York: Peacock Publisher Inc, 1982.

Bayet, Claire Salomon. Jean Jacques Rousseau. Paris: Marabout, 1972.

Biro Pusat Stalistik. Survey Angkatan Kerja Nasional 2000. Jakarta: Instrumen BFS, 2000.

Boudon, Raymond, et all. La Sociologie. Paris: Larousse, 1990.

Bowbly. Separation. New York: Basic Books, 1973.

Brinkerhoiff, David B., White Lynn K. Sociology. New York: West Publishing Company, 1992.

Browne, Ken. An Inroducation to Sociology. New York: Polity Press, 1992.

Chatman, E. A. "Life a Small Word: Applicability of Gratification Theory to Information-Seeking Behavior." Journal of the American Society for Information Science Vol.IV (1991).

Chatman, E. A., Pendleton, V. E. M. Knowledge Gop, Information Seeking and the Poor: RF, 1995.

Dahrendorf, R. "The Service Class.” Inruction Man Ed. Tom Bruns: Penguin Modern, 1970.

Degenhardt, M. A. B. Education and The Volue of Knowledge. London: George Allen \& Unwin, 1982.

Durkheim, Emile. The Division of Labor in Society. Terj Simpson G. Glencoe: The Free Press, 1933. 
Escobar. Miguel. Dialog Bareng Paulo Freire, Sekolah Kapitalisme yang Licik. Terj. Suaedy. Yogyakarta: Lkis, 1998.

ESDP. The ESDP in The Transatelantik Context-Between Aleniation and New Partnership. http://www.uni-koelen .de/wisofak/ PCWI/Wessels/frup/esdp.html.

Fox, Kate. Evaluation Alienation and Gossip: the Role of Mobile Telecommunicationin the 21st Century. http://www.sirc.org/index.html.

Freire, Paulo. Pendidikan Tinggi di Indonesia: Suatu Upaya untuk Memenuhi Kebutuhan System Industri Modern

http://www.pdk.go.id/jurnal/29/penerapan/total/q ualitymanagemen.html.

Fromm, Erich. The Sane Society. New York, 1955.

Gaspersz, Vinoet. Penerapan Total Quality Management in Education (TQME) Pada Perguruan Tinggi di Indonesia: Suatu Upaya untuk Memenuhi Kebutuhan Sistem IndustriModern.

http//www.pdk.go.id/jurnal/29/penerapantotal/qu ality/managemen.htm

Geltran, Cristina Garos. Education Level and Linguistic Repertoire. http://www.urv.es/centres/Departements/dfag/Ga ros.

Geyer, Felix. Alienation Society and Individual: Contynunty and Change in Theory and Reserch. http://www.unizer.es/alienation/ indice.html.

Geyer, Felix. Alienation Participation and Increasing Societal Complexcity. International Conference on "New Trendsin Organitations: Their Impact on Participation, De-alienation, and Performance". Israel: Givat Haviva, 1993.

Gayer, Felix. Sociocybernetic \& The New Alienation.

http://www.unizar.es/sociocybernetics/indicie/ht $\mathrm{ml}$.

Giddens. Anthony The Concequences of Modernity. Cambridge: Polity Press, 1990.

Goldscheider, Calvin. Populasi Modernisasi dan Struktur Sosial. Terj. Achiyat. Jakarta: CV Rajawali, 1985.

Habermas, Juergen. "Theory of Comunicative Action.” Lifeword and System Vol II (1988).

Hall, Richard F. Alienation http://www.seanet.com/realistic/idealism.htm.
Harrison, David. The Sociology of Moderntion and Develowment. London: Unwin Hayman, 1998.

Harvey, Edward B. Industrial Society Structures, Roles, and Relations. The dorsey Press, 1975.

Henry, Michel. Marx une Philosophie de la Realite. Paris: Gallimard, 1976.

Hinshelwood, R. D. Alienation, Social Relations and Therapeutic Relations. http://www.humannature.com/free-associations/hinalien.html.

Hodson, J. Seeking Job Statisfaction. http://www.alien/people.vcu.edu/jmahoney/hods on04.htm.

Hungtington, Samuel P. Dalam Modernization Theories http://www.modernity.polisci.umm.Edu /courses/spring2001/3447/pdf.

Indeks Pembangunan Manusia (IPM) Kotamadya di DKI Jakarta 1990-1999. http://www.bkpmddki.go.id/index.php3

Inkeles, Alex. "The School as a Context for Modernization." Eduction and Individual Modernity in Developing Countries. Ed. Alex Inkelesdan Donald B. Holsinger, Leiden: E.J. Brill, 1974.

Jayaswal, Meera., Singh Amar Kumar. Health Modernity in Triblasof South Bihar. http://www.hsph.havard.edu.html.

Koentjaraningrat. Kebudayaan, Mentalis, dan Pengembangan. Jakarta: Gramedia, 1983.

Kon, Igor S. The Concept of Alienation in Modern Society. http://www.kashimarforum.com/articiles.html

Koperski, Leona M. "Indentifying Cases of Prent Alienation Syndrome." The Colorado Lawyer Vol XXVII (1998).

La Folie.

http,//194.55.36.92/gottlieb/foliemu/htm

Latour, Bruno. Nous N'avons Jamais Ete Modeme, Essai d'Anthrophologie Symentrique. Paris: Editions La Decouverte, 1991.

Lewis, Bemard. "The West and The Middle East." dalam Asghar Ali Islam And Momermity. http//:dawoodi-bohras.com/perspective/isla mod.htm.

Lipset, Seymour M. Dalam What is Political Development?

http://www.modernity.pilisci.uum.edu/courses/sp iring2001/3447/trans/pdf. 
Madjid, Nurcholis. Islam Doktrin dan Peradaban. Jakarta: Yayasan Wakaf Permadani, 1992

Marcuse, Herbert. Eros and Civilization A Philosophical Ingquiry Into Freud. New York: Free Press, 1962.

Martin, Daniel. Accuturation An Universal Process. http,//www.alineagroup com/ acculuration.htm

Marx, Karl. "Alienated Labour.” Industrial Man. Ed Tom Burns. Penguin Education (1983).

Mc Clleand, D.C. The Achieving Society. New York: Free Press, 1976.

Maszaros, Istivan. Alienation The Road to Despair. $\mathrm{http} / / \mathrm{seanet.com} /$ realistic/idealism.html.

O'Donnell, Mike. A New Introduction to Sociology. Thomas Nelson and Sons Ltd, 1992. Parsons, Talcitt., Shils, E. Touward a Greneral The Ory of Action. New York: Harper \& Row, 1962.

Psyschiatrie,

http,//193.55.36.92/gottlieb/pasychiatrie/html

Rais, Amien. Cakrawala Islam antara Cinta dan Fakta. Bandung: Mizan, 1991.

Rakhamat, Jalaudin. "Psikologi dan Agama." Buletin al Tanwir Vol.188 (2001).

Rasmussen. Peter Ravn Education. http,//www.orvina.org.

Rizter, Robet J., Gilmart, Kevin J. "Social Indication of Youth Developement and Edication Perfomance: A Progamatic Statement." Social Indicators Research, an International and Intar Dispilinary Journal for Quality of Life Measurament, Vol.VII (1980).

Rousseau, Jean J. "The Bacic Political Writings," Dalam Bo Li Quality. The Macmillan Ltd, 1933. Savitri, Eva dan Imam Harjono. Penentuan Segemeantasi yang Mendukung Strategi Pemasaran Untuk Transaksi Bisnis Internet Pada Wilayah Bandung. http://www.elektroinindonesia.com / elektro/ 1987.

Seeman, Melvin. "On the Meaning of Alienation." American Sociological Thought, Vol XXI (1987).
Soboul, Albered. LaCivilation et la revolution Fracaise I - La Crise de I'Ancien Regime Paris: Arthaud, 1970.

Steiner Modernity. http://www.mhsc.c/mhsc/modernity.html

Sukaesih. "Hubungan Antara Tingkat Pendidikan, Penghasilan, dan Jenis Pekerjaan Orang Tua dan Perestasi Belajar Anak di Sekolah Dasar Bandung." Laporan Penalitian Falkutas Ilmu Komunikasi Universitas Padjaran Bandung, (1994).

Suriasumantri, Jujun S.“ Pembangunan Sosial Budaya Secara Terpadu." Masalah Budaya Tahun 2000: Sebuah Bunga Rampai Yogyakarta (1986).

Syriati, Ali. "Islam Agama Protes." Terj Satrio Pinandito. Jakarta: Pustaka Hidayah, 1993.

Filsafat Ilmu, Sebuah Pengantar Populer. Jakarta :Sinar Harapan 1984. 
(DAFTAR PUSTAKA versi Petunjuk Penulisan)

[1] Geyer, Felix. Alienation Society and Individual: Contynunty and Change in Theory and Reserch. http://www.unizer.es/alienation/ indice.html.

[2] Igor S. Kon, The Concept of Alienation in Modern Society, pp. 7-10

(http://www.khasmirforum.com/articles/hariomar ticle.html).

[3] Ibid, p.9

[4] Marcuse, Herbert. Eros and Civilization A Philosophical Ingquiry Into Freud. New York: Free Press, 1962.

[5] Ibid 